\title{
Cronobacter sakazakii MEMASUKI KONDISI VIABLE BUT NONCULTURABLE SELAMA PEMBENTUKAN BIOFILM
}

\section{[Cronobacter sakazakii Enters Viable but Nonculturable State during Biofilm Formation]}

\author{
Yesica M. R. Sinaga1), Ratih Dewanti-Hariyadi ${ }^{2,3) \star}$, dan Suliantari ${ }^{2,3)}$ \\ 1) Program Studi IImu Pangan, Sekolah Pasca Sarjana, Institut Pertanian Bogor, Bogor \\ 2) Southeast Asian Food and Agricultural Science and Tecnology Center, Institut Pertanian Bogor, Bogor \\ ${ }^{3)}$ Departemen IImu dan Teknologi Pangan, Fakultas Teknologi Pertanian, Institut Pertanian Bogor, Bogor
}

Diterima 26 September 2016 / Disetujui 15 November 2016

\begin{abstract}
Studies show that nonsporeformer food-borne pathogens may enter a viable but nonculturable (VBNC) state under stress conditions. This research aimed to study the ability of Cronobacter sakazakii to enter a VBNC state during biofilm formation on stainless steel (SS) surfaces and its resuscitability. C. sakazakii YRt2a pGFPuv mutant and wildtype (WT) originally isolated from powder infant formula (PIF) were used in this study. Biofilms were developed on SS surfaces in 1/10 Trypticase Soy Broth (TSB). Culturability of the biofilms was monitored by swabbing and plating the WT or mutant sessile cells onto Trypticase Soy Agar (TSA) or TSA containing $100 \mu \mathrm{g} / \mathrm{mL}$ ampicillin (TSAA), respectively. Meanwhile, their viability was measured using direct microscopic (DMC) count based on green fluorescence for mutant isolates and direct viable count (DVC) for the WT using a fluorescence microscope. Biofilm of $C$. sakazakii pGFPuv mutant on SS entered VBNC state after 25 days of incubation, while the WT C. sakazakii biofilms was still culturable until day 63. Sodium pyruvate in solid and liquid medium was not able to resuscitate the biofilm cells of $C$. sakazakii pGFPuv in VBNC state. C. sakazakii pGFPuv mutants enter VBNC state faster than the WT isolates. Depleted nutrient is thought to drive biofilm of C. sakazakii pGFPuv to enter VBNC.
\end{abstract}

Keywords: biofilm, Cronobacter sakazakii, pGFPuv, sodium pyruvate, viable but nonculturable

\section{ABSTRAK}

Bakteri patogen pangan bukan pembentuk spora dilaporkan dapat memasuki kondisi viable but nonculturable (VBNC) saat mengalami stres. Penelitian ini bertujuan untuk mengetahui kemampuan bakteri Cronobacter sakazakii memasuki kondisi VBNC selama pembentukan biofilm pada permukaan pelat stainless steel (SS) dan kemampuannya untuk diresusitasi. C. sakazakii YRt2a mutan pGFPuv dan wildtype (WT) yang sebelumnya diisolasi dari susu formula bubuk digunakan dalam penelitian ini. Biofilm dibentuk pada permukaan SS dalam 1/10 Trypticase Soy Broth (TSB). Kulturabilitas biofilm diamati dengan menyeka dan menumbuhkan sel sesil WT dan mutan masing-masing di dalam media Trypticase Soy Agar (TSA) atau TSA yang mengandung $100 \mu \mathrm{g} / \mathrm{mL}$ ampisilin (TSAA). Sementara itu, viabilitas sel sesil dihitung menggunakan direct microscopic count (DMC) berdasarkan pendaran hijau untuk isolat mutan dan direct viable count (DVC) untuk WT menggunakan mikroskop fluoresens. Biofilm C. sakazakii mutan pGFPuv pada pelat SS memasuki kondisi VBNC setelah 25 hari inkubasi, sementara biofilm $C$. sakazakii WT masih dapat dikulturkan sampai hari ke-63. Natrium piruvat di dalam media padat dan cair tidak mampu meresusitasi sel biofilm $C$. sakazakii pGFPuv dalam kondisi VBNC. $C$. sakazakii mutan lebih cepat memasuki kondisi VBNC dibandingkan isolat WT. Nutrisi yang semakin berkurang diduga mengakibatkan biofilm C. sakazakii pGFPuv memasuki VBNC.

Kata kunci: biofilm, Cronobacter sakazakii, natrium piruvat, pGFPuv, viable but nonculturable

\section{PENDAHULUAN}

Cronobacter sakazakii adalah salah satu spesies Cronobacter spp yang merupakan bakteri Gram negatif, berbentuk batang, fakultatif anaerob

Naskah telah dipresentasikan dalam International Conference 2016, Food Innovations: AEC Challenges, 21-22 September 2016, Jakarta.

*Penulis Korespondensi: E-mail: rdewantih@yahoo.com dan motil (Healy et al., 2010; Iversen et al., 2008). Cronobacter spp. sebagai bakteri patogen bawaan pangan telah diasosiasikan dengan penyakit septisemia, meningitis dan enterokolitis pada bayi yang baru lahir dan lansia (Emami et al., 2012; Townsend et al., 2008). Kasus infeksi pada bayi oleh Cronobacter spp. telah dilaporkan karena konsumsi susu formula bayi yang tercemar bakteri tersebut. 
C. sakazakii tergolong bakteri yang dapat bertahan dalam kondisi tidak ideal. Cronobacter spp. dilaporkan bertahan lebih baik pada serealia dengan Aw rendah selama 12 bulan dibandingkan dengan pada Aw tinggi (Lin dan Beuchat, 2007). Bakteri ini diketahui dapat menempel dan membentuk biofilm pada permukaan kontak pangan seperti silikon, lateks, polikarbonat, dan stainless steel (Lee et al., 2012; Pratomo, 2015). Kemampuan bakteri $C$. sakazakii ini menempel pada peralatan makan bayi berpotensi menjadi sumber cemaran.

Sel bakteri ketika mengalami stres akan memberi respon yang berbeda, bergantung tingkat keparahan stres. Ketika berada pada lingkungan suboptimal untuk pertumbuhan, bakteri dapat mengalami stres adaptif. Paparan terhadap stres yang lebih besar selanjutnya dapat mengakibatkan injuri pada bakteri. Bakteri yang mengalami injuri dengan keparahan rendah, atau disebut juga mengalami injuri subletal, dapat dipulihkan dengan mudah dalam media nonselektif atau dalam media kaya nutrisi. Injuri bakteri dengan keparahan yang lebih tinggi lagi, dimana pemulihannya memerlukan media dan lingkungan yang lebih kompleks, dapat mengakibatkan masuknya bakteri ke kondisi viable but nonculturabe (VBNC) (Ray dan Bhunia, 2014).

Bakteri yang tidak memiliki kemampuan membentuk spora umumnya dapat memasuki kondisi VBNC sebagai mekanisme pertahanan pada lingkungan yang tidak menguntungkan (Pinto et al., 2011). Bakteri dalam kondisi VBNC masih memiliki viabilitas yang ditandai dengan adanya integritas membran, respirasi, metabolisme, dan mempertahankan transkripsi mRNA tetapi tidak dapat membentuk koloni pada media agar (Pinto et al., 2013). Keberadaan bakteri Cronobacter spp. dalam kondisi VBNC dapat menjelaskan hasil negatif yang diperoleh pada pengujian sampel susu formula bubuk atau produk lainnya yang terkontaminasi bakteri tersebut (Farmer, 2015).

Estimasi jumlah bakteri patogen pada sampel pangan yang lebih rendah dari sebenarnya dan kegagalan mengidentifikasi bakteri patogen saat dikulturkan dapat menimbulkan risiko terkait keamanan pangan (Ramamurthy et al., 2014). Beberapa bakteri dalam kondisi VBNC masih dapat mempertahankan sifat virulensinya. Campylobacter jejuni yang lebih baik dalam mempertahankan kondisi VBNC memiliki virulensi yang lebih tinggi (Magajna dan Schraft, 2015). Sementara E. coli pada kondisi VBNC masih dapat menghasilkan sejumlah kecil verotoksin (Dinu dan Bach, 2011). Meskipun demikian, belum ada laporan mengenai hal tersebut terkait C. sakazakii. C. sakazakii YRt2a yang diisolasi dari susu formula bubuk (Meutia et al., 2008) dan galur mutannya dilaporkan memiliki pola partumbuhan yang sama (Nurjanah et al., 2014). Selama pembentukan biofilm pada berbagai permukaan kontak pangan di dalam media nutrisi rendah, C. sakazakii mutan memberikan hitungan mikroskopik hingga 2 Log sel $/ \mathrm{cm}^{2}$ lebih tinggi daripada hitungan cawan (Pratomo, 2015). Oleh karena itu diduga bakteri ini dapat memasuki kondisi VBNC (Pratomo, 2015). Bakteri dalam kondisi VBNC dapat kembali ke kondisi dapat dikulturkan (culturable) jika berada pada kondisi yang menguntungkan. Perubahan sel bakteri dari kondisi VBNC ke kondisi dimana bakteri dapat dikulturkan disebut resusitasi (Pinto et al., 2011). Sel VBNC Vibrio cholera dan Escherichia coli dapat diresusitasi pada media yang mengandung natrium piruvat dan katalase (Imamura et al., 2015; $\mathrm{Na}$ et al., 2006).

Tujuan penelitian ini adalah mengevaluasi apakah C. sakazakii WT dan mutan pGFPuv dapat memasuki kondisi VBNC selama pembentukan biofilm di dalam media nutrisi rendah. Selain itu, penelitian ini juga bertujuan untuk mengetahui apakah sel VBNC yang terbentuk pada penelitian ini dapat diresusitasi dengan natrium piruvat.

\section{BAHAN DAN METODE}

\section{Bahan}

Bakteri yang digunakan adalah Cronobacter sakazakii wildtype (WT) YRt2a (SEAFAST Center, Indonesia) yang diisolasi dari susu formula bubuk (Meutia et al., 2008) dan Cronobacter sakazakii pGFPuv mutan YRt2a (SEAFAST Center, Indonesia) yang ditransformasi menggunakan metode $\mathrm{CaCl}_{2}$ (Nurjanah et al., 2014).

\section{Persiapan bakteri uji}

Isolat $C$. sakazakii pGFPuv dan WT dari stok manik-manik beku disegarkan dalam BHI (Oxoid Ltd, UK) dengan penambahan ampisilin (PT. Erita Farma, Indonesia) $(100 \mu \mathrm{g} / \mathrm{mL})(\mathrm{BHIA})$ untuk isolat mutan pGFPuv dan tanpa penambahan ampisilin (BHI) (Oxoid Ltd, UK) untuk isolat WT. Bakteri diinkubasi dalam inkubator (Heraeus, Germany) selama 24 jam pada suhu $37^{\circ} \mathrm{C}$. Kultur yang telah disegarkan dikonfirmasi dengan menumbuhkan bakteri pada media TSA (Oxoid Ltd, UK) dengan penambahan ampisilin $100 \mu \mathrm{g} / \mathrm{mL}$ (TSAA) untuk bakteri mutan pGFPuv dan DFI (Oxoid Ltd, UK) untuk isolat WT, kemudian bakteri diinkubasi pada suhu $37^{\circ} \mathrm{C}$ selama 24 jam. Pengamatan koloni yang tumbuh pada media TSAA (Oxoid Ltd, UK) dilakukan di bawah lampu UV (Desaga, Heidelberg, Germany) dengan panjang gelombang $366 \mathrm{~nm}$. Isolat yang telah dikonfirmasi pada TSAA dan DFI masing-masing diambil satu ose dan dimasukkan ke dalam BHIA (Oxoid Ltd, UK) atau BHI lalu diinkubasi pada suhu $37^{\circ} \mathrm{C}$ selama $16-17$ jam sampai fase logaritmik akhir sehingga diperoleh kultur dengan populasi sel sekitar $10^{8}-10^{9} \mathrm{CFU} / \mathrm{mL}$ (Nurjanah et 
al., 2013). Sebelum diinokulasikan ke dalam media yang akan digunakan untuk menginduksi kondisi VBNC, masing-masing $1 \mathrm{~mL}$ kultur dari BHIA dan $\mathrm{BHI}$ disentrifugasi (HERMLE Z383K, Germany) dengan kecepatan 4500 rpm selama 10 menit pada suhu $4^{\circ} \mathrm{C}$ untuk mendapatkan massa sel. Kemudian dilakukan pencucian dengan $1 \mathrm{~mL}$ BPW (Oxoid Ltd, UK) dan disentrifugasi kembali selama 4 menit pada kecepatan $4500 \mathrm{rpm}$ suhu $4^{\circ} \mathrm{C}$. Pelet diresuspensi dalam $1 \mathrm{~mL}$ BPW. Masing-masing inokulum siap digunakan untuk induksi kondisi VBNC.

\section{Pembentukan biofilm untuk menginduksi kondisi VBNC}

Pembentukan biofilm dilakukan pada stainless steel (SS) berukuran $1 \mathrm{~cm} \times 1 \mathrm{~cm}$. Sebelum digunakan pelat direndam dalam larutan deterjen komersial selama 1 jam kemudian dibilas dengan akuades. Pelat dikeringkan lalu dibersihkan dengan alkohol $70 \%$ (Merck, USA). Setelah proses sanitasi pelat dikeringkan pada suhu $55^{\circ} \mathrm{C}$ selama 1 malam menggunakan inkubator (H.ORTH GmbH, West Germany) (Marques et al., 2007).

Pembentukan biofilm dilakukan berdasarkan Pratomo (2015) dengan modifikasi. Modifikasi yang dilakukan adalah konsentrasi media yang digunakan (dari 1/5 TSB menjadi 1/10 TSB) dan jumlah mikroba awal dari (dari $10^{5} \mathrm{CFU} / \mathrm{mL}$ menjadi $10^{7}$ $\mathrm{CFU} / \mathrm{mL}$ ). Media dengan nutrisi rendah (1/10 dari takaran pembuatan TSB yang ditetapkan produsen) $200 \mathrm{~mL}$ yang telah berisi pelat SS disterilisasi pada suhu $121^{\circ} \mathrm{C}$ selama 15 menit (ALP Co.,Ltd, Tokyo, Japan). Masing-masing inokulum $C$. sakazaki pGFPuv dan WT hasil sentrifugasi yang telah disiapkan sebelumnya, sebanyak $2 \mathrm{~mL}$ diinokulasikan ke dalam media tersebut sehingga diperoleh jumlah mikroba awal $10^{7} \mathrm{CFU} / \mathrm{mL}$. Sampel diinkubasi pada suhu kamar $\left(28-30^{\circ} \mathrm{C}\right)$ dengan agitasi $70 \mathrm{rpm}$ (Innova $^{\mathrm{TM}}$ 2300, New Brunswick Scientific, New Jersey, USA). Pada interval waktu tertentu pelat SS diambil dan dilakukan penghitungan viabilitas dan kulturabilitas sel biofilm.

\section{Pengamatan viabilitas dan kulturabilitas sel biofilm}

Viabilitas sel biofilm diamati menggunakan mikroskop fluoresens (Olympus $\mathrm{CH} 3 \mathrm{O}$, Olympus Corporation, Center Valley, PA, USA) pada panjang gelombang $395 \mathrm{~nm}$ dan emisi $509 \mathrm{~nm}$. Biofilm $C$. sakazakii pGFPuv pada permukaan SS dibilas menggunakan garam fisiologis (GF) (Merck, USA) $0,85 \%$ steril dan ditiriskan kemudian diamati di bawah mikroskop fluoresens (Pratomo, 2015). Sel yang berfluoresens saat pengamatan kemudian dihitung dengan metode DMC (Parizzi et al., 2004). Untuk biofilm $C$. sakazakii WT pengamatan viabilitas dilakukan dengan metode DVC (modifikasi Du et al., 2007). Modifikasi yang dilakukan yaitu perubahan suhu inkubasi dari $26^{\circ} \mathrm{C}$ menjadi suhu ruang (28$30^{\circ} \mathrm{C}$ ) dan waktu inkubasi dari 16 jam menjadi 18 jam. Setelah biofilm pada SS dibilas, pelat direndam dalam larutan yang mengandung yeast extract (Oxoid Ltd, UK) dan asam nalidiksat (Sigma-Aldrich, USA) dengan konsentrasi masing-masing 0,025\% dan $0,002 \%$ pada suhu ruang dan kondisi gelap selama 18 jam. Berikutnya pelat dibilas dengan GF $0,85 \%$ steril dan dilanjutkan dengan pewarnaan menggunakan acridine orange 0,0026\% (SigmaAldrich, USA) selama 5 menit (Pratomo, 2015). Pelat SS kemudian diamati di bawah mikroskop fluoresens. Sel viabel adalah sel yang mengalami perubahan bentuk memanjang atau membesar (Du et al., 2007). Untuk setiap penghitungan viabilitas, jumlah pelat SS yang diamati sebanyak 2 pelat. Sebanyak 10 bidang pandang diamati di bawah mikroskop fluoresens untuk setiap pelat (Parizzi et al., 2004). Hasil perhitungan yang diperoleh dinyatakan dalam bentuk Log $\mathrm{sel} / \mathrm{cm}^{2}$.

Kulturabilitas diamati dengan menghitung koloni pada media agar. Biofilm pada permukaan SS dibilas dengan GF 0,85\% steril dan diusap dengan kapas steril. Hasil usapan biofilm C. sakazakii pGFPuv atau WT masing-masing dimasukkan ke dalam tabung yang berisi $9 \mathrm{~mL}$ BPW dan $1 \mathrm{~mL}$ Naheksametafosfat $\quad 0,1 \% \quad$ (Sigma-Aldrich, USA) (Pratomo, 2015). Tabung kemudian divortex (Vortex Genie 2, Scientific Industries Inc., USA), dan 0,1 mL masing-masing isolat tersebut disebar dalam media TSAA atau TSA dalam cawan yang diinkubasi selama 24 jam pada suhu $37^{\circ} \mathrm{C}$. Koloni yang tumbuh kemudian dihitung. Kondisi VBNC dianggap tercapai jika bakteri sudah tidak membentuk koloni pada media agar tetapi masih dapat dihitung dengan DMC atau DVC (Pinto et al., 2013).

\section{Resusitasi di dalam media padat dan cair}

Resusitasi menggunakan media padat dilakukan dengan menumbuhkan sebanyak $0,1 \mathrm{~mL}$ sel biofilm hasil usapan dalam tabung yang berisi BPW+Na-heksametafosfat seperti yang sudah dijelaskan sebelumnya ke dalam media agar TSAA dan TSA yang mengandung natrium piruvat $0,1 \%$ (9 $\mathrm{mM}$ ) (Sigma-Aldrich, USA) (Imamura et al., 2015). Cawan yang berisi media agar kemudian diinkubasi selama 24 jam. Sementara itu, resusitasi menggunakan media cair dilakukan dalam BPW yang mengandung natrium piruvat $0,1 \%$ (9 mM) (modifikasi Wai et al., 2000). Modifikasi yang dilakukan adalah perubahan air steril menjadi BPW. Resusitasi dalam media cair dilakukan hanya untuk isolat mutan saja. Hasil usapan biofilm dalam tabung BPW+Na-heksametafosfat sebanyak $0,1 \mathrm{~mL}$ dimasukkan pada $10 \mathrm{~mL}$ media cair dan diinkubasi selama 24 jam untuk resusitasi pada suhu $37^{\circ} \mathrm{C}$ (Heraeus, Germany). Sebanyak 0,1 mL suspensi bakteri hasil inkubasi disebar pada media TSAA 
untuk melihat ada tidaknya pembentukan koloni. Jika setelah inkubasi 24 jam resusitasi belum berhasil, inkubasi diperpanjang hingga 72 jam kemudian ditumbuhkan kembali pada media TSAA.

\section{HASIL DAN PEMBAHASAN}

\section{Viabilitas dan kulturabilitas Cronobacter sakazakii pGFPuv dan Cronobacter sakazakii WT selama pembentukan biofilm}

Sel biofilm C. sakazakii pGFPuv yang terbentuk pada permukaan SS menunjukkan viabilitas dan kulturabilitas yang baik pada hari ke-7 dengan jumlah sel viabel $0,8 \mathrm{Log} \mathrm{sel} / \mathrm{cm}^{2}$ lebih tinggi dibandingkan jumlah sel yang dapat dikulturkan (Gambar 1). Bakteri sesil mutan ini terlihat berpendar hijau di bawah mikroskop fluoresens pada panjang gelombang $396 \mathrm{~nm}$ yang menandakan viabilitas (Gambar 2) sesuai Shimomura (2009). Penggunaan GFP untuk mengamati kondisi VBNC juga telah dilakukan pada E. coli (Dinu dan Bach, 2011). Dengan bertambahnya waktu inkubasi, perbedaan antara jumlah sel viabel dan jumlah sel yang dapat dikulturkan semakin besar (Gambar 1). Pada hari ke-15 jumlah sel viabel mencapai $4,4 \pm 0,15 \mathrm{Log} \mathrm{sel} / \mathrm{cm}^{2}$ sementara jumlah sel yang dapat dikulturkan turun menjadi 1,4 $\pm 0,22$ Log $\mathrm{CFU} / \mathrm{cm}^{2}$ hingga akhir pengamatan (hari ke-25) jumlah sel viabel mencapai $3,9 \pm 0,01 \mathrm{Log} \mathrm{sel} / \mathrm{cm}^{2}$ tetapi tidak mampu lagi membentuk koloni saat ditumbuhkan dalam media TSAA.

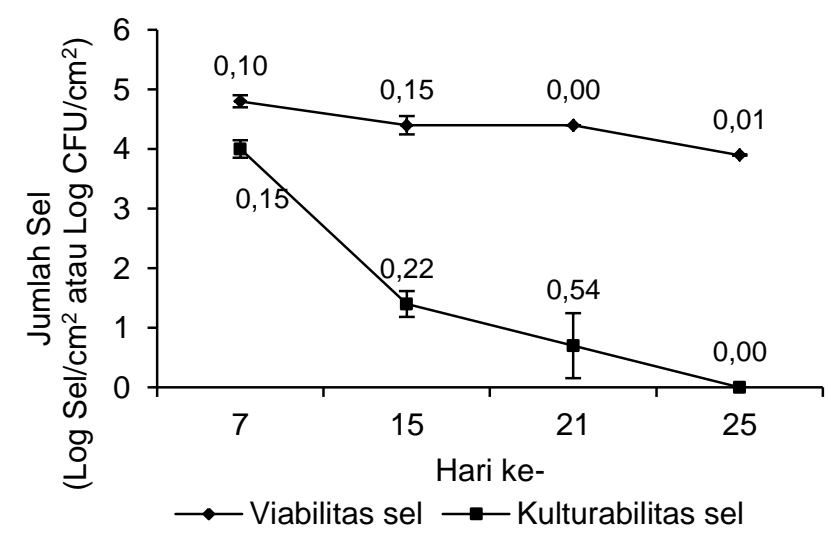

Gambar 1. Viabilitas (Log sel $/ \mathrm{cm}^{2}$ ) dan kulturabilitas (Log CFU $/ \mathrm{cm}^{2}$ ) C. sakazakii mutan pGFPuv selama pembentukan biofilm

Perbedaan antara jumlah sel yang viabel dengan sel yang dapat dikulturkan mengindikasikan bakteri berada dalam kondisi VBNC (Oliver, 2009). Hasil penelitian ini menunjukkan biofilm C. sakazakii pGFPuv memasuki kondisi VBNC pada hari ke-25 inkubasi di dalam media 1/10 TSB. Masuknya bakteri dalam kondisi VBNC merupakan respon ter- hadap nutrisi yang berkurang selama waktu inkubasi. Selain itu, kondisi di dalam struktur biofilm sendiri juga memberikan stres berupa ketersediaan nutrisi yang terbatas dibanding lapisan luar biofilm (Stewart dan Franklin, 2008). Sel biofilm yang memasuki kondisi VBNC belum pernah dilaporkan untuk bakteri C. sakazakii tetapi sudah dilaporkan pada bakteri lain. Sel biofilm Campylobacter jejuni memasuki kondisi VBNC akibat stres berupa inkubasi di dalam media nutrisi rendah phosphate buffered saline (PBS) dan suhu rendah $4^{\circ} \mathrm{C}$ (Magajna dan Schraft, 2015). Sel biofilm C. jejuni tersebut memasuki kondisi VBNC dalam 10-20 hari inkubasi. Sel biofilm Staphylococcus aureus yang diinkubasi pada suhu $37^{\circ} \mathrm{C}$ dalam media minimal M9 tanpa glukosa memasuki kondisi VBNC setelah 40 hari inkubasi (Pasquaroli et al., 2013).

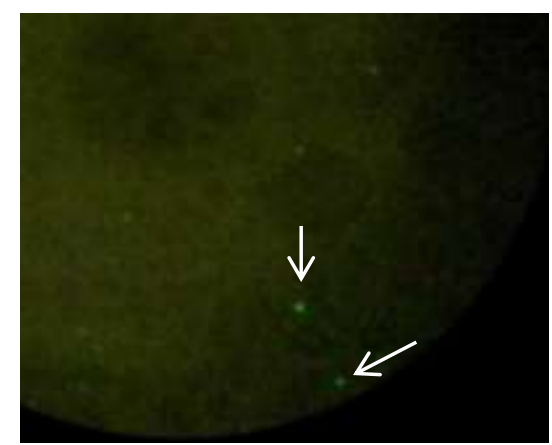

Gambar 2. Sel biofilm C. sakazakii YRt2a pGFPuv hari ke-25 di bawah mikroskop fluoresens (1000x). Tanda panah menunjukkan sel yang berfluoresens

Pengamatan viabilitas isolat WT di bawah mikroskop fluoresens disajikan pada Gambar 3. Viabilitas ditandai dengan adanya sel yang memanjang sesuai dengan $\mathrm{Na}$ et al. (2006) yang juga mengamati sel VBNC E. coli dengan metode DVC. Dengan metode ini, yeast extract yang ditambahkan berperan sebagai sumber nutrisi yang akan dimetabolisme oleh sel yang viabel sementara asam naildiksat berperan sebagai inhibitor spesifik replikasi DNA yang mencegah pembelahan sel sehingga dihasilkan sel yang memanjang atau membesar (Babu et al., 2014).

Berbeda dengan isolat mutan, viabilitas dan kulturabilitas sel biofilm isolat $C$. sakazakii WT pada hari ke-7 menunjukkan perbedaan lebih besar yakni 2 Log (Gambar 4). Meskipun demikian, viabilitas isolat WT relatif lebih stabil selama 56 hari inkubasi dengan jumlah sel biofilm berkisar antara 4,1-4,3 Log sel/ $\mathrm{cm}^{2}$. Penurunan dalam jumlah kecil sel viabel $(0,4 \mathrm{Log})$ terjadi pada akhir pengamatan (hari ke-63). Sementara itu kulturabilitas isolat WT yang pada awal pengamatan berjumlah 2,1 $\pm 0,34$ Log $\mathrm{CFU} / \mathrm{cm}^{2}$ menunjukkan penurunan seiring bertambahnya waktu inkubasi meski dalam jumlah kecil $(0,8$ Log selama 63 hari inkubasi). Pada akhir 
pengamatan (hari ke-63) sel biofilm WT masih dapat

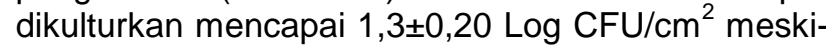
pun jumlah ini lebih kecil dibandingkan viabilitas

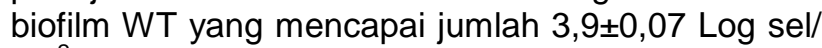
$\mathrm{cm}^{2}$. Perbedaan antara viabilitas dan kulturabilitas sel bakteri yang mengalami stres dapat menimbulkan kesalahan penghitungan jumlah bakteri pada pengujian pangan dengan metode hitungan cawan seperti yang diungkapkan Farmer (2015). Oleh sebab itu keberadaan bakteri yang mengalami stres, seperti kondisi VBNC perlu diwaspadai saat melakukan pengujian pangan.

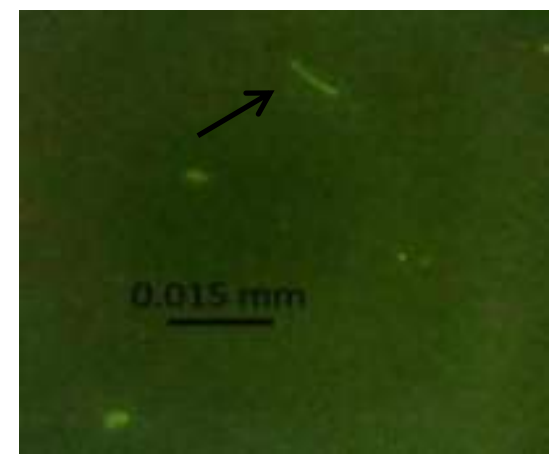

Gambar 3. Sel biofilm C. sakazakii WT pada hari ke-63 yang diamati menggunakan metode DVC di bawah mikroskop fluoresens (1000x). Tanda panah menunjukkan sel yang memanjang

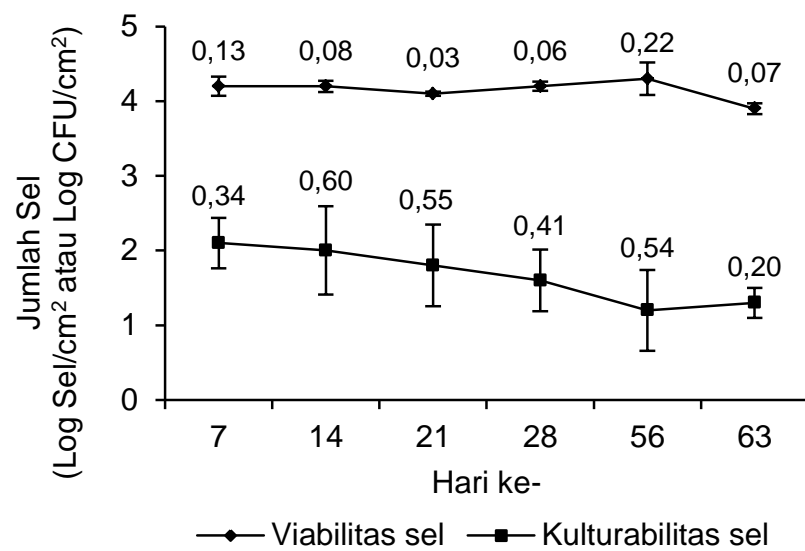

Gambar 4. Viabilitas ( $\log \mathrm{sel} / \mathrm{cm}^{2}$ ) dan kulturabilitas (Log CFU $\left./ \mathrm{cm}^{2}\right)$ C. sakazakii mutan pGFPuv selama pembentukan biofilm

Sel biofilm mutan sudah memasuki kondisi VBNC pada hari ke-25 sedangkan biofilm isolat WT masih dapat dikulturkan hingga hari ke-63. Perbedaan respon sel biofilm mutan dan WT terhadap stres berupa kekurangan nutrisi mungkin di-pengaruhi oleh penyisipan GFP pada bakteri mutan. Allison dan Sattenstall (2007) melaporkan bahwa GFP yang disisipkan pada bakteri Escherichia coli memiliki efek signifikan terhadap sifat fisiologis bakteri tersebut dan mengakibatkan bakteri menjadi lebih rentan terhadap stres senyawa antimikroba dibandingkan dengan bakteri WT. Adanya protein GFP dapat menimbulkan stres fisiologis pada bakteri dengan mengalihkan fungsi-fungsi seluler penting bakteri untuk mereplikasi protein asing tersebut dalam jumlah tinggi. Oleh karena itu diduga protein GFP pada bakteri $C$. sakazakii mutan memberikan pengaruh pada pertumbuhan bakteri saat menghadapi stres sehingga menunjukkan perbedaan dengan isolat WT yang tidak disisipi GFP. Nurjanah et al. (2014) memperlihatkan tidak adanya perbedaan yang signifikan antara kurva pertumbuhan sel planktonik $C$. sakazakii isolat mutan dan WT. Akan tetapi, pengujian pertumbuhan isolat mutan dan WT ini dilakukan pada kondisi pertumbuhan optimal yaitu dalam media $\mathrm{BHI}$ yang tidak memberikan stres nutrisi rendah.

\section{Resusitasi C. sakazakii pGFPuv dan C. sakazakii WT di dalam media padat dan cair}

Resusitasi sel VBNC bakteri C. sakazakii pGFPuv pada hari ke-26 di dalam media padat TSAA yang disuplementasi natrium piruvat tidak mampu mengembalikan kemampuan bakteri untuk membentuk koloni (Tabel 1). Penggunaan media cair BPW yang disuplementasi dengan natrium piruvat juga tidak berhasil meresusitasi sel VBNC bakteri $C$. sakazakii pGFPuv bahkan setelah perpanjangan inkubasi 72 jam di dalam media cair (Tabel 1).

Tabel 1. Resusitasi C. sakazakii pGFPuv dalam media padat dan cair

\begin{tabular}{|c|c|c|c|}
\hline \multicolumn{3}{|c|}{ Jenis Media } & Resusitasi \\
\hline \multirow{2}{*}{$\begin{array}{l}\text { Media } \\
\text { padat }\end{array}$} & TSAA+natrium piruvat & & - \\
\hline & TSAA kontrol & & - \\
\hline \multirow{4}{*}{$\begin{array}{l}\text { Media } \\
\text { cair }\end{array}$} & BPW+natrium piruvat & 24 jam & - \\
\hline & BPW kontrol & & - \\
\hline & BPW+natrium piruvat & 48 jam & - \\
\hline & BPW kontrol & & - \\
\hline
\end{tabular}

Sel biofilm isolat WT hari ke-63 juga tidak mengalami peningkatan jumlah sel yang dapat dikulturkan saat ditumbuhkan pada media yang ditambahkan piruvat (Gambar 5). Tidak ada perbedaan jumlah koloni yang terbentuk pada media TSA dengan $\left(1,2 \pm 0,20 \mathrm{Log} \mathrm{CFU} / \mathrm{cm}^{2}\right)$ atau tanpa

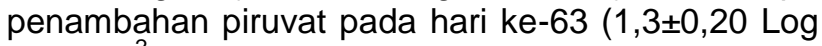
$\left.\mathrm{CFU} / \mathrm{cm}^{2}\right)$. Penambahan natrium piruvat hanya dilakukan pada media pertumbuhan padat untuk isolat WT karena sel biofilm masih dapat dikulturkan hingga hari ke-63. Hasil penelitian ini memperlihatkan natrium piruvat tidak dapat digunakan untuk mempermudah deteksi bakteri $C$. sakazakii yang berada pada kondisi VBNC. Oliver (2009) menjelaskan bahwa $\mathrm{H}_{2} \mathrm{O}_{2}$ baik yang diproduksi oleh sel 
bakteri ketika dicawankan atau yang secara alami terdapat pada media agar, berpengaruh pada kondisi VBNC Vibrio vulnificus. Pada kondisi stres suhu rendah, ekpresi gen katalase (katG) menurun seiring dengan kemampuan pembentukan koloni yang juga menurun. Natrium piruvat merupakan senyawa yang dapat mereduksi $\mathrm{H}_{2} \mathrm{O}_{2}$ (Reissbrodt et al., 2002). Oleh sebab itu natrium piruvat dapat digunakan untuk resusitasi sel VBNC. Selain itu piruvat juga diketahui sebagai penyedia sumber energi yang dimetabolisme dengan cepat dan efisien (Guccione et al., 2008).

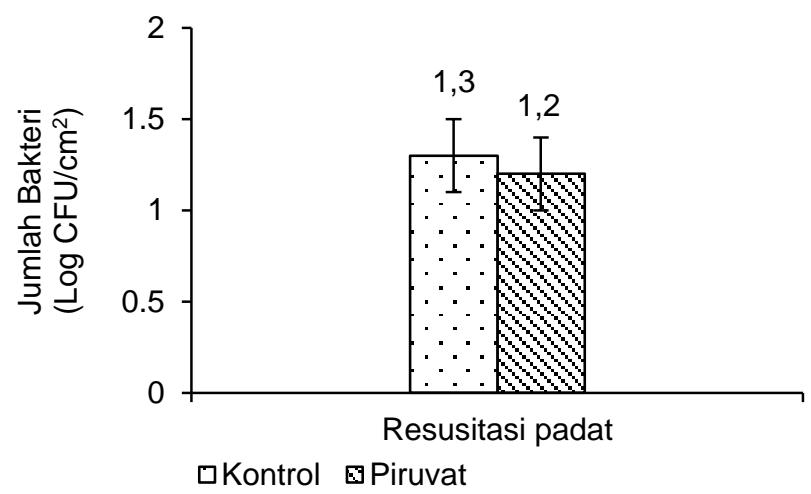

Gambar 5. Resusitasi C. sakazakii WT di dalam media padat TSA

Pada penelitian ini, penambahan natrium piruvat dalam media TSAA atau TSA tidak dapat meningkatkan kulturabilitas baik sel biofilm isolat mutan maupun WT. Hal ini diduga terjadi karena masuknya sel biofilm ke dalam kondisi VBNC tidak disebabkan oleh sel yang sensitif terhadap $\mathrm{H}_{2} \mathrm{O}_{2}$. Ketidakmampuan senyawa pereduksi $\mathrm{H}_{2} \mathrm{O}_{2}$ dalam resusitasi sel $C$. sakazakii VBNC memberikan bukti bahwa kondisi VBNC pada bakteri tidak hanya disebabkan oleh sensitivitas sel terhadap akumulasi $\mathrm{H}_{2} \mathrm{O}_{2}$ yang mencegah sel untuk dikulturkan (Lleo et al., 2001). Ketidakberhasilan resusitasi sel VBNC di dalam media yang disuplementasi senyawa antioksidan seperti katalase maupun natrium piruvat sudah dilaporkan pada sel Listeria monocytogenes yang memasuki VBNC setelah inkubasi dalam air Milli-Q pada suhu $4^{\circ} \mathrm{C}$ (Lindback et al., 2010) sel VBNC E. coli yang diinkubasi dalam air keran pada suhu $23^{\circ} \mathrm{C}$ (Aurass et al., 2011) dan sel biofilm $S$. aureus yang memasuki kondisi VBNC setelah 40 hari inkubasi dalam media nutrisi rendah M9 tanpa glukosa (Pasquaroli et al., 2013). Meskipun demikian beberapa penelitian lainnya menunjukkan sel VBNC dapat diresusitasi menggunakan senyawa antioksidan. Media yang mengandung natrium piruvat berhasil meresusitasi sel biofilm VBNC Campylobacter jejuni yang memasuki VBNC dalam 10-20 hari (Magajna dan Schraft, 2015) dan sel biofilm $S$. aureus yang memasuki kondisi VBNC $\leq$
30 hari akibat inkubasi dalam media M9 tanpa glukosa yang mengandung antibiotik vankomisin atau dalfopristin (Pasquaroli et al., 2013).

Hasil penelitian Pinto et al. (2011) menunjukkan bahwa sel VBNC yang tidak mampu diresusitasi dengan natrium piruvat dapat diresusitasi dengan senyawa lain seperti asam amino dan Al (autoinducer) dari Enterobacteriaceae. Selain itu faktorfaktor lain yang dapat meresusitasi sel VBNC adalah sel eukariotik (Senoh et al., 2010) dan senyawa antioksidan lainnya seperti ferrioxamine $E$ dan oksirase (Reissbrodt et al., 2002) juga telah dilaporkan. Senyawa-senyawa atau faktor-faktor yang dapat meresusitasi sel yang berada dalam keadaan VBNC akan mempermudah deteksi bakteri VBNC pada pangan.

\section{KESIMPULAN}

C. sakazakii pGFPuv dapat memasuki kondisi VBNC selama pembentukan biofilm di dalam media dengan nutrisi rendah 1/10 TSB. Pada hari ke-25 biofilm $C$. sakazakii pGFPuv sudah memasuki kondisi VBNC dengan jumlah sel viabel 3,9 Log $\mathrm{sel} / \mathrm{cm}^{2}$. Sementara C. sakazakii WT hingga hari ke63 masih memiliki sel yang dapat dikulturkan dengan jumlah 1,3 Log $\mathrm{CFU} / \mathrm{cm}^{2}$ dan sel viabel berjumlah $3,9 \mathrm{Log} \mathrm{sel} / \mathrm{cm}^{2}$. Resusitasi yang dilakukan dengan menambahan natrium piruvat ke dalam media padat dan cair tidak berhasil meningkatkan jumlah koloni sel biofilm C. sakazakii. Perlu dilakukan penelitian lanjutan untuk mendapatkan senyawa yang dapat meresusitasi sel VBNC $C$. sakazakii sehingga mempermudah deteksi bakteri tersebut dalam bahan pangan.

\section{DAFTAR PUSTAKA}

Allison DG, Sattenstall MA. 2007. The influence of green fluorescent protein incorporation on bacterial physiology: a note of caution. J Appl Microbiol 103: 318-324. DOI: 10.1111/j.13652672.2006.03243.x.

Auras $P$, Prager R, Flieger A. 2011. EHEC/EAEC O104:H4 strain linked with the 2011 German outbreak of haemolytic uremic syndrome enters into the viable but non-culturable state in response to various stresses and resuscitates upon stress relief. Environ Microbiol 13: 31393148. DOI: 10.1111/j.1462-2920.2011.02604.x.

Babu D, Kushwaha K, Juneja VK. 2014. Viable but nonculturable. Encyclop Food Microbiol 3: 686690. DOI: 10.1016/B978-0-12-384730-0.004249.

Dinu LD, Bach S. 2011. Induction of viable but nonculturable Escherichia coli $\mathrm{O} 157: \mathrm{H} 7$ in the 
phyllosphere of lettuce: a food safety risk factor. Appl Environ Microb 77: 8295-8302. DOI: 10.11 28/AEM.05020-11.

Du M, Chen J, Zhang X, Li A, Li Y, Wang Y. 2007. Retention of virulence in a viable but nonculturable Edwardsiella tarda isolate. Appl Environ Microb 73: 1349-1354. DOI: 10.1128/ AEM.02243-06.

Emami CN, Mittal R, Wang L, Ford HR, Prasadarao NV. 2012. Role of neutrophils and macrophages in the pathogenesis of necrotizing enterocolitis caused by Cronobacter sakazakii. J Surg Res 172: 18-28. DOI: 10.1016/j.jss.20 11.04.019.

Farmer JJ. 2015. Review: My 40-year history with Cronobacter/Enterobacter sakazakii - lessons learned, myths debunked, and recommendations - a review. Front Pediatric 3: 1-12. DOI: 10.3389/fped.2015.00084.

Guccione E, Leon-Kempis MD, Pearson BM, Hitchin E, Mulholland F, van Diemen PM, Stevens MP, Kelly DJ. 2008. Amino acid-dependent growth of Campylobacter jejuni: key roles for aspartase (AspA) under microaerobic and oxygen-limited conditions and identification of AspB (Cj0762), essential for growth on glutamate. Mol Microbiol 69: 77-93. DOI: 10.1111/j.1365- 2958.2008.0 6263.x.

Healy B, Cooney S, O'Brien S, Iversen C, Whyte P, Nally J, Callanan JJ, FanningS. 2010. Cronobacter (Enterobacter sakazakii): An oppurtunistic foodborne pathogen. Foodborne Pathog Dis 7: 339-350. DOI: 10.1089/fpd.2009.0379.

Imamura D, Mizuno T, Miyoshi S, Shinoda S. 2015. Stepwise changes in viable but nonculturable Vibrio cholerae cells. Microbiol Immunol 59: 305-310. DOI: 10.1111/1348-0421.12246.

Iversen C, Mullane N, McCardell B, Tall BD, Lehner A, Fanning S, Stephan R, Joosten H. 2008. Cronobacter gen. nov., a new genus to accomodate the biogroups of Enterobacter sakazakii, and proposal of Cronobacter sakazakii gen. nov., comb. nov., Cronobacter malonaticus sp. nov., Cronobacter turicensis sp. Nov., Cronobacter muytjensii sp. nov., Cronobacter dublinensis sp. nov., Cronobacter genomospecies 1 , and of three subspecies, Cronobacter dublinensis subsp. Dublinensis subsp nov., Cronobacter dublinensis subsp. lausannensis subsp. nov. And Cronobacter dublinensis subsp. lactaridi subsp. Int J Syst Evol Micr 58: 1442-1447. DOI: 10.1099/ ijs.0.65577-0.

Lee YD, Park JH, Chang H. 2012. Detection, antibiotic susceptibility and biofilm formation of Cronobacter spp. from various foods in Korea.
Food Control 24: 225-230. DOI: 10.1016/j.food cont.2011.09.023.

Lin LC, Beuchat LR. 2007. Survival of Enterobacter sakazakii in infant cereal as affected by composition, water activity, and temperature. Food Microbiol 24: 767-777 DOI: 10.1016/j.fm. 2007.02.001.

Lindback T, Rottrnberg ME, Roche S, Rorvik LM. 2010. The ability to enter into an avirulent viable but non-culturable (VBNC) form is widespread among Listeria monocytogenes isolates from salmon, patients and environment. Vet Res 41: 08. DOI: $10.1051 /$ vetres/2009056.

Lleo MM, Bonato B, Tafi MC, Signoretto C, Boaretti M, Canepari. 2001. Resuscitation rate in different enterococcal species in the viable but nonculturable state. J Appl Micobiol 91: 10951102. DOI: 10.1046/j.1365-2672.2001.01476.x.

Magajna BA, Schraft H. 2015. Campylobacter jejuni biofilm cells become viable but nonculturable (VBNC) in low nutrient conditions at $4^{\circ} \mathrm{C}$ more quickly than their planktonic counterparts. Food Control 50: 45-50. DOI: 10.1016/j.foodcont.20 14.08.022.

Marques SC, Rezende JGOS, de Freitas Alves LA, Silva BC, Alves E, de Abreu LR, Piccoli RH. 2007. Formation of biofilms by Staphylococcus aureus on stainless steel and glass surfaces and its resistance to some selected chemical sanitizers. Brazil J Microbiol 38: 538-543. DOI: 10.1590/S1517-83822007000300029.

Meutia YR, Dewanti-Hariyadi R, Estuningsih $S$. 2008. Karakteristik gen penyandi $16 \mathrm{~S}$ rRNA Enterobacter sakazakii yang diisolasi dari susu formula. Dipresentasikan pada Pertemuan Tahunan Perhimpunan Ahli Teknologi Pangan, Palembang, Oktober 2008.

$\mathrm{Na}$ SH, Miyanaga K, Unno H, Tanji Y. 2006. The survival response of Escherichia coli K12 in a natural environment. Appl Microbiol Biotechnol 72: 386-392. DOI: 10.1007/s00253-005-0268-3.

Nurjanah S, Suhartono MT, Dewanti-Hariyadi R, Estuningsih S. 2013. Aplikasi mutan berfluoresens untuk mempelajari ketahanan hidup kolonisasi dan penetrasi isolat Cronobacter sakazakii selama pengeringan jagung. J Teknol Industri Pangan 24: 184-193. DOI: 10.6066/jtip. 2013.24.2.184.

Nurjanah S, Dewanti-Hariyadi R, Estuningsih S, Suhartono T. 2014. Stability and growth characteristic of GFPuv-labeled Cronobacter sakazakiii isolated from foods. Food Science Biotechnol 23: 1491-1496. DOI: 10.1007/s100 68-014-0204-3. 
Oliver JD. 2009. Recent findings on the viable but nonculturable state in pathogenic bacteria - a review. FEMS Microbiol Rev 34: 415-425. DOI: 10.1111/j.1574-6976.2009.00200.x.

Parizzi SQF, Andrade NJd, Silva CAdS, Soares NdFF, Silva EAMd. 2004. Bacterial adherence to different inert surfaces evaluated by epifluorescence microscopy and plate count method. Braz Arch Biol Technol Microbiol 47: 77-83. DOI: 10.1590/S1516-891320040001000 11.

Pasquaroli S, Zandri G, Vignaroli C, Vuotto C, Donelli G, Biavasco F. 2013. Antibiotic pressure can induce the viable but nonculturable state in Staphylococcus aureus growing in biofilms. J Antimicrob Chemoth 68: 1812-1817. DOI: 10.10 93/jac/dkt086.

Pinto D, Almeida V, Santos MA, Chambel L. 2011. Resuscitation of Escherichia coli VBNC cells depends on a variety of environmental or chemical stimuli. J Appl Microbiol 110: 16011611. DOI: 10.1111/j.1365-2672.2011.05016.x.

Pinto D, Santos MA, Chambel L. 2013. Thirty years of viable but nonculturable state research: Unsolved molecular mechanisms [review]. Crit Rev Microbiol 41: 1-16. DOI: 10.3109/1040841 X.2013.794127.

Pratomo YA. 2015. Penggunaan Mutan C. sakazakii untuk Kajian Pembentukan Biofilm Multispesies. [Tesis]. Bogor: Fakultas Teknologi Pertanian, Institut Pertanian Bogor.

Ramamurthy T, Ghosh A, Pazhani GP, Shinoda S. 2014. Current perspective on viable but nonculturable (VBNC) pathogenic bacteria. Frontier Public Health 2: 1-9. DOI: 10.3389/fpubh.20 14.00103.
Ray B, Bhunia A. 2014. Fundamental Food Microbiology $5^{\text {th }}$ Ed. 99-115. CRC Press, New York, US.

Reissbrodt R, Rienaecker I, Romanova JM, Freestone PPE, Haigh RD, Lyte M, Tschape H, Williams PH. 2002. Resuscitation of Salmonella enterica Serovar Typhimurium and enterohemorrhagic Escherichia coli from the viable but nonculturable state by heat-stable enterobacterial autoinducer. Appl Environ Microbiol 68: 4788-4794. DOI: 10.1128/AEM.68.10.47884794.2002

Senoh M, Ghosh-Banerjee, Ramamurthy $T$, Hamabata T, Kurakawa T, Takeda M, Colwell RR, Nair GB, Takeda Y. 2010. Conversion of viable but nonculturable Vibrio cholerae to the culturable state by co-culture with eukaryotic cells. Microbiol Immunol 54: 502-507. DOI: 10.1111/j.1348-0421.2010.00245.x.

Shimomura O. 2009. Discovery of green fluorescent protein (GFP) (nobel lecture). Angew Chem Int Ed 48: 5590-5602. DOI: 10.1002/anie.20090 2240.

Stewart PS, Franklin MJ. 2008. Physiological heterogeneity in biofilms. Nat Rev Microbiol 6: 199-210. DOI: 10.1038/nrmicro1838.

Townsend SM, Hurrell E, Caubilla-Barron J, LocCarrillo C, Forsythe SJ. 2008. Virulence studies of Enterobacter sakazakii isolates associated with a neonatal intensive care unit outbreak. BMC Microbiol 8: 64. DOI: 10.1186/1471-21808-64.

Wai SN, Mizunoe Y, Takade A, Yoshida S. 2000. A comparison of solid and liquid media for resuscitation of starvation- and low-temperatureinduced nonculturable cells of Aeromonas hydrophila. Arch Micorbiol 173: 307-310. DOI: $10.1007 / \mathrm{s} 002030000142$. 